\title{
PENGARUH CITRA MEREK, KUALITAS PRODUK DAN KUALITAS PELAYANAN TERHADAP KEPUASAN PELANGGAN Studi Pada Pelanggan Datsun di PT. Indomobil Trada Nasional Cabang Kebon Jeruk
}

\author{
Lucy Nancy \\ mamaolgalucy@yahoo.co.id
}

Jurusan Manajemen, Fakultas Ekonomi, Universitas Satya Negara Indonesia Jalan Arteri Pondok Indah No.11 Jakarta Selatan

\begin{abstract}
The purpose of this study to analyze the effect of Brand Image, Product Quality and Service Quality on Customers Satisfaction. The population in this study are all customers Datsun in PT. Indomobil Trada Nasional Kebon Jeruk unknown number. Total sample of 60 people with the method of Non-Probability sampling with Accidental Sampling technique.The method of collecting data using a survey questionnaire. Analysis of data using multiple linear regression with SPSS 22. The results showed that the partial t test known brand image variable has significant effect on customers satisfaction, product quality variable did not significantly effect on customers satisfaction and service quality variable has significantly effect on customers satisfaction. Based on F test found that the variable Brand Image, Product Quality and Service Quality simultaneously significant effect on customers satisfaction.
\end{abstract}

Keywords: Brand, Product Quality, Service Quality and Customer Satisfaction

\section{PENDAHULUAN}

Industri otomotif terus mengalami peningkatan, hal ini didorong oleh kebutuhan masyarakat terhadap alat transportasi untuk mendukung aktivitas masyarakat seharihari.Adanya alat transportasi umum saat ini dirasa kurang memenuhi kebutuhan masyarakat. Hal ini disebabkan karena kendaraan umum banyak sekali kekurangan, seperti kurangnya jaminan faktor keamanan dan kenyamanan bagi penumpang, jadwal kedatangan angkutan yang sering terlambat, biaya karcis harian yang jika dihitung totalnya akan lebih mahal dibandingkan dengan jika memakai mobil pribadi yang cukup mengisi bahan bakar untuk beberapa hari perjalanan, rute kendaraan umum yang tidak bisa langsung mencapai tujuan, dan masih banyak lagi pertimbangan-pertimbangan sehingga masyarakat lebih memilih mobil pribadi sebagai alat transportasi mereka.

Meningkatnya jumlah pendapatan juga turut mendorong masyarakat untuk memiliki kendaraan pribadi. Masyarakat yang tadinya hanya memakai motor atau angkutan umum, karena meningkatnya pendapaan mereka ingin memiliki mobil pribadi yang terjangkau dengan teknologi modern, bisa mengangkut banyak orang, irit bahan bakar dan tentunya minim biaya perawatan. Sebagian masyarakat menganggap kepemilikan mobil pribadi 
akan meningkatkan derajat seseorang di mata masyarakat. Masyarakat masih menganggap mobil pribadi sebagai salah satu lambang kesuksesan seseorang dalam bekerja.

Terbitnya Peraturan Menteri Perindustrian No. 33/M-IND/PER/7/2013 Tentang pengembangan Produksi Kendaraan Bermotor Roda Empat yang Hemat Energi dan Harga Terjangkau, Selanjutnya kebijakan ini lebih terkenal dengan sebutan mobil murah ramah ligkungan atau Low Cost Green Car (LCGC).Hal ini tentunya menjadi angin segar bagi industri otomotif di Indonesia untuk memenuhi kebutuhan masyarakat terhadap kebutuhan mobil pribadi dengan harga terjangkau. Beberapa merek perusahaan otomotif berlomba memproduksi mobil LCGC dengan kelebihannya masing-masing untuk memenuhi kebutuhan masyarakat ini.

\section{Tabel 1}

\section{Daftar Merek Mobil LCGC di Indonesia}

\begin{tabular}{|c|l|}
\hline No & \multicolumn{1}{|c|}{ MEREK } \\
\hline 1 & Toyota Agya \\
\hline 2 & Daihatsu Ayla \\
\hline 3 & Honda Brio Satya \\
\hline 4 & Datsun GO \&GO+Panca \\
\hline 5 & Suzuki Karimun Wagon \\
\hline
\end{tabular}

Sumber:Data Sekunder Diolah (2016)

Berdasarkan tabel, menunjukkan merek-merek produk yang dihadirkan perusahaan otomotif. Beragam merek dengan jenis produk yang sama ini tentunya membuat persaingan antar merek semakin ketat. Merek Datsun yang kembali dihidupkan oleh Nissan Co.Ltd.dipasar Indonesia hadir untuk turut serta dalam memenuhi kebutuhan masyarakat untuk memiliki mobil pribadi yang terjangkau. Walaupun merek Datsun baru setahun diluncurkan jumlah penjualan Datsun terus mengalami peningkatan.Sepertinya penggunaan merek Datsun yang terkenal Durable (Tangguh), Attractive (Menarik), dan Thrustworthy (Terpercaya) meningkatkan animo masyarakat untuk memilih merek Datsun sebagai mobil pribadi pertama mereka.

Pada kenyataannya masing-masing merek tentunya memiliki kelebihan dan kekurangan terkait dengan kualitas produk.Baik buruknya kualitas sebuah produk menjadi salah satu penentu bagi seseorang dalam memilih sebuah merek produk.Meningkatnya kesadaran masyarakat akan pentingnya kualitas produk yang dibeli, mengharuskan Datsun untuk meningkatkan kualitas produknya untukmemenuhi kepuasan pelanggan sehingga produknya dapat terus berkembang dimasa depan.

Keinginan pelanggan untuk mendapatkan produk yang berkualitas mendorong perusahaan untuk terus berinovasi.Kepuasan pelanggan juga tergantung dari kualitas produk dan jasa. Tidak jarang karena tingginya tuntutan pelanggan akan produk yang berkualitas terkadang membuat pelanggan kecewa dan merasa tidak puas karena produk yag didapatkan tidak sesuai dengan harapan dan berujung di kolom surat pembaca media. 
Lebih merugikan lagi bagi kelangsungan produk jika pengaduan sampai berujung di meja hijau.

Meningkatnya jumlah pelanggan Datsun dan fitur-fitur pada produk mobil Datsun yang cangih tentunya membutuhkan tempat perawatan yang mudah dijangkau bagi pelanggan, peralatan modern dan teknisi yang tersertifikasi untuk merawat mobil pelanggan. PT. Indomobil Group hadir dengan jumlah 110 dealer di Indonesia, dan terus akan membuka dealer-dealer baru untuk mendekatkan diri kepada pelanggan. Kualitas Pelayanan yang baik menjadi prioritas bagi dealer dan merupakan keharusan untuk meraih kepuasan pelanggan ketika melakukan perawatan mobilnya di dealer. Meningkatnya jumlah pelanggan yang memanfaatkan jasa pelayanan perawatan kendaraan ini tentunya harus dikelola secara serius oleh pihak dealer untuk memberikan kepuasan kepada pelanggan. Sering pelanggan merasa kecewa terhadap suatu merek atau produk bukan karena merek atau produk tersebut tidak bagus, akan tetapi karena pelanggan mendapatkan pelayanan yang buruk dari karyawan atau kondisi lokasi pelayanan yang tidak layak. Pelayanan yang baik biasanya akan memberikan tingkat kepuasan yang tinggi bagi pelanggan.

Menurut Keller (2013:549) "Citra Merek adalah persepsi konsumen dan preferensi untuk merek, diukur dengan berbagai jenis asosiasi merek yang ada dalam memori konsumen".

Menurut Menurut Kotler dan Amstrong (2014:253) "Kualitas Produk adalah karakteristik sebuah produk atau jasa yang memberikan kemampuan untuk mencukupi kebutuhan pelanggan".

Menurut Tjiptono (2014:268) "Kualitas Jasa/Pelayanan adalah berfokus kepada upaya pemenuhan kebutuhan dan keinginan pelanggan serta ketepatan penyampaiannya untuk mengimbangi harapan pelanggan".

Menurut Tjiptono (2014:353) "Kepuasan Pelanggan adalah sebagai respon pelanggan terhadap evaluasi ketidak sesuaian (disconfirmation) yang dipersepsikan antara harapan awal sebelum pembelian (atau norma kinerja lainnya) dan kinerja aktual produk yang dipersepsikan setelah pemakaian atau konsumsi produk bersangkutan".

Berdasarkan latar belakang yang sudah dijelaskan maka penulis merasa perlu untuk melakukan penelitian dengan judul "PENGARUH CITRA MEREK, KUALITAS PRODUK dan KUALITAS PELAYANAN TERHADAP KEPUASAN PELANGGAN" (Studi Pada Pelanggan Datsun di PT. Indomobil Trada Nasional Cabang Kebon Jeruk).

\section{KERANGKA PEMIKIRAN TEORITIS}

\section{Citra Merek}

Pengertian Citra Merek menurut Keller (2013:549) Citra Merek adalah persepsi konsumen dan preferensi untuk merek, diukur dengan berbagai jenis asosiasi merek yang ada dalam memori konsumen.

\section{Kualitas Produk}

Menurut Kotler dan Amstrong (2014:253) Kualitas Produk adalah karakteristik sebuah produk atau jasa yang memberikan kemampuan untuk mencukupi kebutuhan pelanggan. 


\section{Kualitas Pelayanan}

Menurut Tjiptono (2014:268) Kualitas Jasa/Pelayanan adalah berfokus kepada upaya pemenuhan kebutuhan dan keinginan pelanggan serta ketepatan penyampaiannya untuk mengimbangi harapan pelanggan

\section{Kepuasan Pelanggan}

Menurut Tjiptono (2014:353) Kepuasan Pelanggan adalah sebagai respon pelanggan terhadap evaluasi ketidaksesuaian (disconfirmation) yang dipersepsikan antara harapan awal sebelum pembelian (atau norma kinerja lainnya) dan kinerja aktual produk yang dipersepsikan setelah pemakaian atau konsumsi produk bersangkutan.

\section{Penelitian Terdahulu}

M. Igor Beladin, Bambang Munas Dwiyanto (2013). Hasil penelitian menunjukkan Kualitas Produk, Kualitas Pelayanan dan Citra Merek berpengaruh positif dan signifikan terhadap kepuasan konsumen. Kualitas produk paling dominan mempengaruhi kepuasan konsumen dan citra merek paling sedikit mempengaruhi kepuasan konsumen. Mario Christo Pesoth (2015). Hasil penelitian menunjukkan Kualitas Produk, Packaging dan Brand Image secara simultan berpengaruh positif terhadap Kepuasan Pelanggan. Secara Parsial Kualitas Produk dan Packaging berpengaruh signifikan terhadap Kepuasan Pelanggan.Brand Image secara Parsial tidak berpengaruh terhadap kepuasan pelanggan.

Nurul Qomariah (2012). Hasil penelitian menunjukkan Kualitas Layanan tidak berpengaruh signifikan terhadap Kepuasan dan Loyalitas Mahasiswa. Variabel Citra Institusi berpengaruh signifikan terhadap Kepuasan Mahasiswa tapi tidak berpengaruh signifikan terhadap Loyalitas Mahasiswa. Muhamad Rizan, Fajar Andika (2011). Hasil penelitian menunjukkan Kualitas Produk berpengaruh Negatif terhadap Kepuasan Pelanggan, Kualitas Pelayanan berpengaruh positif terhadap Kepuasan Pelanggan, dan Kualitas Produk dan Kualitas Pelayanan secara simultan berpengaruh positif terhadap Kepuasan Pelanggan.

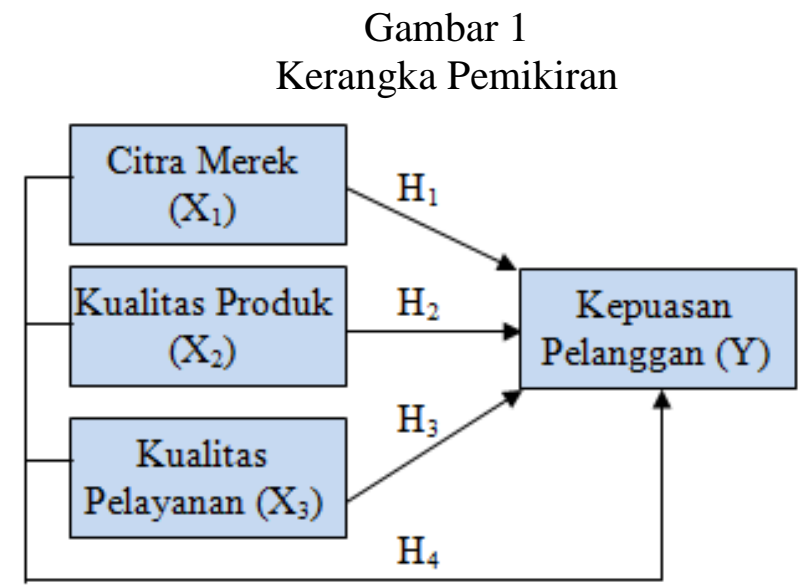

Sumber. Data Sekunder Diolah (2016)

$\mathrm{H}_{01} \quad$ : Tidak terdapat pengaruh yang signifikan antara Citra Merek terhadap Kepuasan Pelanggan.

$\mathrm{H}_{\mathrm{a} 1} \quad$ :Terdapat pengaruh yang signifikan antara Citra Merek terhadap Kepuasan Pelanggan. 


$\begin{array}{ll}\mathrm{H}_{02} & \begin{array}{l}\text { :Tidak terdapat pengaruh yang signifikan antara Kualitas Produk terhadap } \\ \text { Kepuasan Pelanggan. } \\ \text { : Terdapat pengaruh yang signifikan antara Kualitas Produk terhadap } \\ \mathrm{H}_{\mathrm{a} 2}\end{array} \\ \mathrm{H}_{03} \text { Kepuasan Pelanggan. } \\ \text { :Tidak terdapat pengaruh yang signifikan antara Kualitas Pelayanan terhadap } \\ \text { Kepuasan Pelanggan. } \\ \mathrm{H}_{\mathrm{a} 3} \quad \begin{array}{l}\text { :Terdapat pengaruh yang signifikan antara Kualitas Pelayanan terhadap } \\ \text { Kepuasan Pelanggan. } \\ \mathrm{H}_{04} \quad \text { Tidak terdapat pengaruh yang signifikan secara simultan antara Citra Merek, } \\ \text { Kualitas Produk dan Kualias Pelayanan terhadap Kepuasan Pelanggan. } \\ \mathrm{H}_{\mathrm{a} 4} \quad \text { :Terdapat pengaruh yang signifikan secara simultan antara Citra Merek, } \\ \text { Kualitas Produk dan Kualias Pelayanan terhadap Kepuasan Pelanggan. }\end{array}\end{array}$

\section{METODE}

\section{Waktu dan Tempat Penelitian}

Penelitian ini dilaksanakan di PT. Indomobil Trada Nasionalcabang Kebon Jeruk yang beralamat di Jalan Arteri Kelapa Dua No.30 Kebon Jeruk, Jakarta Barat, 11550mulai dari bulan Maret 2016 sampai dengan Juni 2016.

\section{Desain Penelitian}

Penelitian ini menggunakan desain Penelitian Kausal Komparatif.Menurut Kotler dan Amstrong (2014:129) Kausal Komparatif adalah Riset Pemasaran yang dilakukan untuk menguji Hipotesis tentang hubungan sebab akibat.Mengetahui variabel yang menjadi penyebab atau variabel pengaruh(variabel independent) dan variabel yang menjadi akibat atau variabel terpengaruh (variabel dependent).

\section{Populasi dan Sampel}

Menurut Sugiyono(2013:119)Populasi adalah wilayah generalisasi yang terdiri atas obyek-obyek yang mempunyai kualitas dan karakteristik tertentu yang di tetapkan oleh peneliti untuk di pelajari dan kemudian di tarik kesimpulan.Populasi dalam penelitian ini adalah seluruh pelanggan Datsun yang melakukan perawatan kendaraan di PT. Indomobil Trada Nasional cabang Kebon Jeruk yang jumlahnya tidak diketahui.

Menurut Sugiyono (2013:120) Sampel adalah bagian dari jumlah dan karakteristik yang di miliki oleh populasi tersebut.Teknik sampling yang digunakan adalah Non Probabilaty Samplingdengan metode Accidental Samplingmenggunakan rumus Roschoe (dalam Sugiyono, 2011:90), $\mathrm{n}=(\mathbf{1 0 s} / \mathbf{d 2 0}) \times \mathbf{k}=(15) \times \mathbf{4}=\mathbf{6 0}, \mathrm{n}=\mathrm{jumlah}$ sampel, $\mathrm{k}=\mathrm{jumlah}$ variabel penelitian yang digunakan, $15 \mathrm{~s} / \mathrm{d} 20=$ jumlah observer menurut Roschoe makadiperoleh sebanyak 60 responden dengan kriteria responden melakukan perawatan minimal 2 kali di PT. Indomobil Trada Nasional.

\section{Metode Pengumpulan Data}

Teknik pengumpulan data menggunakan teknik Survey dengan kuesioner sebagai instrumen pengumpulan data. Kuisioner merupakan metode pengumpulan data yang dilakukan dengan cara memberikan seperangkat pernyataan tertulis kepada responden yang terpilih. 


\section{Definisi Operasionalisasi Variabel Variabel Independen}

1. Citra Merek $\left(\mathbf{X}_{1}\right)$

Pengertian Citra Merek menurut Keller (2013:549) Citra Merek adalah persepsi konsumen dan preferensi untuk merek, diukur dengan berbagai jenis asosiasi merek yang ada dalam memori konsumen.

\section{Kualitas Produk $\left(\mathbf{X}_{2}\right)$}

Menurut Kotler dan Amstrong (2014:253) Kualitas Produk adalah karakteristik sebuah produk atau jasa yang memberikan kemampuan untuk mencukupi kebutuhan pelanggan.

\section{Kualitas Pelayanan $\left(\mathbf{X}_{3}\right)$}

Menurut Tjiptono (2014:268) Kualitas Jasa/Pelayanan adalah berfokus kepada upaya pemenuhan kebutuhan dan keinginan pelanggan serta ketepatan penyampaiannya untuk mengimbangi harapan pelanggan

\section{Variabel Dependen}

Menurut Tjiptono (2014:353) Kepuasan Pelanggan (Y) adalah sebagai respon pelanggan terhadap evaluasi ketidaksesuaian (disconfirmation) yang dipersepsikan antara harapan awal sebelum pembelian (atau norma kinerja lainnya) dan kinerja aktual produk yang dipersepsikan setelah pemakaian atau konsumsi produk bersangkutan.

\section{Metode Analisis Data}

\section{Uji Instrumen}

a. Uji Validitas

Uji Validitas digunakan untuk mengukur valid atau tidaknya suatu kuesioner, Ghozali (2013:51).

b. Uji Reliabilitas

Uji Reliabilitas digunakan untuk mengukur suatu kuesioner yang merupakan indikator dari variabe, Ghozali (2013:47).

\section{Uji Asumsi Klasik}

a. Uji Normalitas

Uji Normalitas pada model regresi digunakan untuk menguji apakah nilai residual yang dihasilkan dari regresi terdistribusi secara normal atau tidak, Ghozali (2013:160).Model regresiyang baik adalah yang memiliki nilai residual yang terdistribusi secara normal.Dalam penelitian ini uji Normalitas menggunakan uji grafik P-Plot.

b. Uji Heteroskedastisitas

Uji Heteroskedastisitas digunakan untuk menguji apakah dalam sebuah model regresi terjadi ketidaksamaan varians dan residual dari satu pengamatan ke pengamatan lain,Ghozali (2013:139).

\section{c. Uji Multikolinearitas}


Uji Multikoliniearitas bertujuan untuk mengetahui apakah terdapat hubungan linier yang sempurna atau mendekati sempurna antar variabel bebas (independent variable), Ghozali (2013:105).

\section{d. Uji Autokorelasi}

Uji Autokorelasi digunakan untuk mengetahui ada atau tidaknya penyimpangan asumsi klasik autokorelasi yaitu korelasi yang terjadi antara residual pada satu pengamatan dengan pengamatan lain pada model regresi, Ghozali (2013:110).

\section{Uji Hipotesis}

a. Uji F

Uji F dikenal dengan Uji serentak atau uji Model/Uji Anova, yaitu uji untuk melihat bagaimanakah pengaruh semua variabel bebasnya secara bersama-sama terhadap variabel terikatnya.

b. Uji t

Uji t dikenal dengan uji parsial, yaitu untuk menunjukkan seberapa jauh satu variabel independent secara individual dalam menerangkan variasi variabel dependent, Ghozali (2013:98).

\section{PEMBAHASAN}

\section{Analisis Data}

\section{Uji Hipotesis}

a. Uji F

Menggunakan tingkat signifikasi 0,05 , dengan df1 = jumlah variabel-1 hasilnya 4-1 $=3$. Df $2=\mathrm{n}-\mathrm{k}-1$ hasilnya $60-3-1=56$ dimana $\mathrm{n}$ adalah jumlah sampel, $\mathrm{k}$ adalah jumlah variabel independent. Duwi Priyatno 2014:158) maka didapat nilai $F_{\text {tabel }}$ sebesar 2,769.

Tabel 2

\section{Hasil Uji F}

\begin{tabular}{|l|r|r|r|r|l|}
\hline Model & \multicolumn{1}{c|}{$\begin{array}{c}\text { Sum of } \\
\text { Squares }\end{array}$} & \multicolumn{1}{c|}{ Df } & Mean Square & F & Sig. \\
\hline Regression & 106.908 & 3 & 35.636 & 25.000 & $.000^{\mathrm{b}}$ \\
1 Residual & 79.825 & 56 & 1.425 & & \\
Total & 186.733 & 59 & & & \\
\hline
\end{tabular}

Sumber : Data Primer Diolah (2016)

Pada tabel 2, menunjukkan hasil uji $\mathrm{F}$ dengan nilai sebesar 25,000 $>2,769$ ( $\mathrm{F}_{\text {hitung }}$ $\left.>\mathrm{F}_{\text {tabel }}\right)$ dan signifikasi $0,000<0,05, \mathrm{H}_{0}$ ditolak. Artinya variabel independent (Citra Merek, Kualitas Produk dan Kualitas Pelayanan) secara bersamasama/simultan berpengaruh positif dan signifikan terhadap variabel dependent (Kepuasan Pelanggan).

b. Uji t

Menggunakan tingkat signifikasi $0,05 / 2=0,025$, dengan derajat kebebasan $\mathrm{df}=\mathrm{n}$ k-1 atau 60-3-1 = 56 dimana (n) adalah jumlah sampel, (k) adalah jumlah variabel

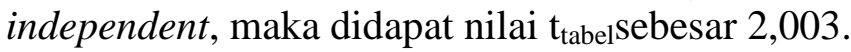


Tabel 3

Hasil Uji t

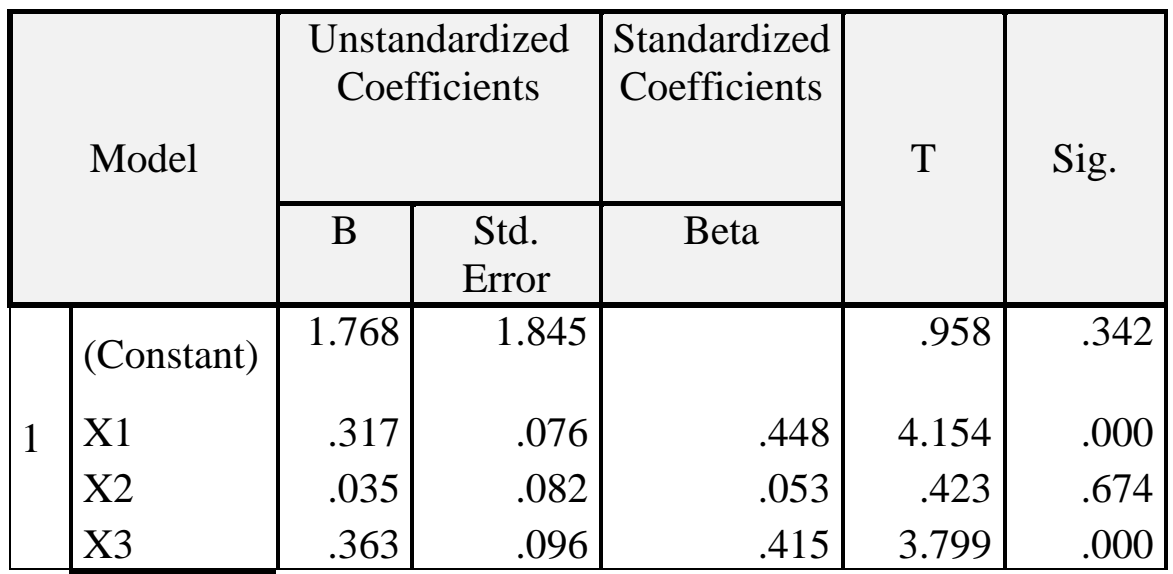

Sumber :Data Primer Diolah(2016

Hasil uji t dari tabel 3, dapat dijelaskan sebagai berikut :

a. Variabel Citra Merek $\left(\mathrm{X}_{1}\right)$ nilai $\mathrm{t}_{\text {hitung }}>\mathrm{t}_{\text {tabel }}(4,154>2,003)$ dan Signifikasi $<0,05$ $(0,000<0,05)$ maka $\mathrm{H}_{0}$ ditolak, artinya Citra Merek berpengaruh signifikan terhadap Kepuasan Pelanggan.

b. Variabel Kualitas Produk $\left(\mathrm{X}_{2}\right)$ nilai $\mathrm{t}_{\text {hitung }}<\mathrm{t}_{\text {tabel }}(0,423<2,003)$ dan Signifikasi $>$ $0,05(0,674>0,05)$ maka $\mathrm{H}_{0}$ diterima, artinya Kualitas Produk tidak berpengaruh signifikan terhadap Kepuasan Pelanggan.

c. Variabel Kualitas Pelayanan $\left(X_{3}\right)$ nilai $t_{\text {hitung }}>t_{\text {tabel }}(3,799>2,003)$ dan Signifikasi $<0,05(0,000<0,05)$ maka $\mathrm{H}_{0}$ ditolak, artinya Kualitas Pelayanan berpengaruh signifikan terhadap Kepuasan Pelanggan.

\section{Persamaan Regresi Linear Berganda}

Tabel 4

Hasil Uji Regresi Linear Berganda

\begin{tabular}{|c|c|c|c|c|c|c|c|c|}
\hline & \multirow{2}{*}{ Model } & \multicolumn{2}{|c|}{$\begin{array}{c}\text { Unstandardized } \\
\text { Coefficients }\end{array}$} & \multirow{2}{*}{$\begin{array}{l}\text { Standardized } \\
\text { Coefficients } \\
\text { Beta }\end{array}$} & \multirow{2}{*}{$\mathrm{T}$} & \multirow{2}{*}{ Sig. } & \multicolumn{2}{|c|}{$\begin{array}{l}\text { Collinearity } \\
\text { Statistics }\end{array}$} \\
\hline & & B & $\begin{array}{l}\text { Std. } \\
\text { Error }\end{array}$ & & & & $\begin{array}{c}\text { Toleran } \\
\text { ce }\end{array}$ & VIF \\
\hline \multirow{4}{*}{1} & (Constant & 1.768 & 1.845 & & .958 & .342 & & \\
\hline & $\mathrm{X} 1$ & .317 & .076 & .448 & 4.154 & .000 & .657 & 1.522 \\
\hline & $\mathrm{X} 2$ & .035 & .082 & .053 & .423 & .674 & .494 & 2.025 \\
\hline & X3 & .363 & .096 & .415 & 3.799 & .000 & .639 & 1.566 \\
\hline
\end{tabular}

a. Dependent Variable: Y

Sumber :Data Primer Diolah(2016) 


$$
Y=1,768+0,317 X_{1}+0,035 X_{2}+0,363 X_{3}
$$

Hasil dari persamaan Regresi Linear Berganda tersebut dapat dijelaskan sebagai berikut:

a. Nilai Konstanta $=1,768$. Artinya jika Citra Merek, Kualitas Produk dan Kualitas Pelayanan nilainya 0 maka Kepuasan Pelanggan bernilai positif sebesar 1,768.

b. Koefisien Regresi Citra Merek $\left(\mathrm{X}_{1}\right)$ bernilai positif sebesar 0,317. Artinya jika variabel Citra Merek meningkat 1 satuan dengan asumsi variabel lain tetap (Cateris Paribus), maka Kepuasan Pelanggan meningkat sebesar 0,317.

c. Koefisien Regresi Kualitas Produk $\left(\mathrm{X}_{2}\right)$ bernilai positif sebesar 0,035. Artinya jika variabel Kualitas Produk meningkat 1 satuan dengan asumsi variabel lain tetap (Cateris Paribus), maka Kepuasan Pelanggan meningkat sebesar 0,035.

d. Koefisien Regresi Kualitas Pelayanan $\left(\mathrm{X}_{3}\right)$ bernilai positif sebesar 0,363. Artinya jika variabel Kualitas Pelayanan meningkat 1 satuan dengan asumsi variabel lain tetap (Cateris Paribus), maka Kepuasan Pelanggan meningkat sebesar 0,363

\section{Koefisien Determinasi}

Koefisien Determinasi $\left(\mathrm{R}^{2}\right)$ mengukur seberapa jauh kemampuan model dalam menerangkan variasi variabel dependen.Nilai Koefisien Determinasi $\left(\mathrm{R}^{2}\right)$ adalah antara0 dan 1.Jika $\mathrm{R}^{2}$ semakin mendekati 1 yang berarti mendekati $100 \%$, artinya variabel independent berpengaruh kuat terhadap variabel dependent.

Dari tabel 5, dapat dilihat bahwa nilai R Square sebesar 0,573 (57,3\%).Nilai 0,573 > 0,50 berarti tinggi ketepatannya, artinya menunjukkan bahwa persentase sumbangan pengaruh variabel independent(Citra Merek, Kualitas Produk dan Kualitas Pelayanan) terhadap variabel dependent (Kepuasan Pelanggan) adalah sebesar 57,3\%. Sedangkan sisanya sebesar $42,7 \%$ dipengaruhi atau dijelaskan oleh variabel lain yang tidak termasuk dalam penelitian.

Tabel 5

Hasil Uji Koefisien Determinasi

\begin{tabular}{|l|r|r|r|r|}
\hline Model & R & R Square & $\begin{array}{c}\text { Adjusted R } \\
\text { Square }\end{array}$ & $\begin{array}{c}\text { Std. Error of } \\
\text { the Estimate }\end{array}$ \\
\hline 1 & $.757^{\mathrm{a}}$ & .573 & .550 & 1.194 \\
\hline
\end{tabular}

Sumber :Data Primer Diolah(2016)

\section{Pembahasan}

1. Variabel Citra Merek terhadap kepuasan pelanggan

Variabel Citra Merek berpengaruh terhadap Kepuasan Pelanggan.Latar belakang merek Datsun yang baik mendorong terciptanya Kepuasan Pelanggan.Hal ini sesuai dengan teori yang menyatakan bahwa Citra Merek yang positif dapat memberikan nilai kepuasan bagi pelanggan.

2. Variabel Kualitas Produk terhadap Kepuasan Pelanggan

Variabel Kualitas Produk tidak berpengaruh terhadap Kepuasan Pelanggan. Artinya responden dalam penelitian ini sudah yakin dan percaya dengan Kualitas Produk 
Datsun yang terjamin kualitasnya, sehingga lebih memperhatikan aspek kepuasan pelanggan yang lain seperti Citra Merek dan Kualitas Pelayanan.

Hal ini sesuai dengan teori yang menyatakan bahwa penilaian Kualitas Produk akan menghasilkan penilaian puas atau tidak puas terhadap produk yang dikonsumsi. Kepuasan terhadap produk akan mendorong konsumen untuk membeli dan mengonsumsi ulang produk tersebut, sebaliknya perasaan tidak puas akan menyebabkan konsumen kecewa dan menghentikan pembelian kembali dan konsumsi produk tersebut. Perusahaan sebaiknya terus meningkatkan Kualitas Produk untuk mempertahankan Kepuasan Pelanggan.

3. Variabel Kualitas Pelayanan terhadap Kepuasan Pelanggan

Variabel Kualitas Pelayanan berpengaruh terhadap Kepuasan Pelanggan.Pelanggan menilai kualitas layanan yang diberikan sudah baik dan sesuai dengan harapan mereka,sehingga pelanggan puas.Hal ini sesuai dengan teori yang menyatakan bahwa Kualitas Pelayanan adalah berfokus kepada upaya pemenuhan kebutuhan dankeinginan pelanggan sertaketepatanpenyampaiannyauntuk mengimbangi harapan pelanggan.Pelanggan akan sangat puas bila mendapatkan pelayanan yang melebihi harapannya.

Sementara itu hasil penelitian ini jika dibandingkan dengan penelitian-penelitian sebelumnya yang relevan adalah sebagai berikut :

1. Variabel Citra Merek Terhadap Kepuasan Pelanggan

Variabel Citra Merek berpengaruh terhadap Kepuasan Pelanggan. Hasil penelitian ini sependapat dengan hasil penelitian sebelumnya yang dilakukan oleh M. Igor Beladin, Bambang Munas Dwiyanto (2013) Judul penelitian : "Analisis Pengaruh Kualitas Produk, Kualitas Pelayanan, dan Citra Merek Terhadap Kepuasan Konsumen”. Dimana pada penelitiannya menunjukkan Citra Merek berpengaruh positif dan signifikan terhadap Kepuasan Konsumen.

2. Variabel Kualitas Produk Terhadap Kepuasan Pelanggan

Variabel Kualitas Produk tidak berpengaruh terhadap Kepuasan Pelanggan.Hasil penelitian ini tidak sependapat dengan hasil penelitian sebelumnya yang dilakukan oleh M. Igor Beladin, Bambang Munas Dwiyanto (2013) Judul penelitian : "Analisis Pengaruh Kualitas Produk, Kualitas Pelayanan, dan Citra Merek Terhadap Kepuasan Konsumen". Dimana pada penelitiannya menunjukkan Kualitas Produk berpengaruh positif dan signifikan terhadap Kepuasan Konsumen.

3. Variabel Kualitas Pelayanan Terhadap Kepuasan Pelanggan.

Variabel Kualitas Pelayanan berpengaruh terhadap Kepuasan Pelanggan.Hasil penelitian ini sependapat dengan hasil penelitian sebelumnya yang dilakukan oleh $\mathrm{M}$. Igor Beladin, Bambang Munas Dwiyanto (2013) Judul penelitian : "Analisis Pengaruh Kualitas Produk, Kualitas Pelayanan, dan Citra Merek Terhadap Kepuasan Konsumen”. Dimana pada penelitiannya menunjukkan Kualitas Pelayanan berpengaruh positif dan signifikan terhadap Kepuasan Konsumen.

\section{PENUTUP}

Berdasarkan hasil pengujian dan pembahasan maka dapat disimpulkan bahwa variabel citra merek, kualitas produk dan kualitas pelayanan secara simulltan berpengaruh terhadap kepuasaan pelanggan. Hasil penelitian juga menunjukan secara parsial hanya 
variabel citra merek dan kualitas pelayanan yang berpengaruh terhadap kepuasaan pelanggan sementara variabel kualitas produk secara parsial tidak berpengaruh terhadap kepuasan pelanggan.

Berdasarkan kesimpulan dari penelitian, ada beberapa saran untuk pihak perusahaan dan akademisi, yaitu :

1. Bagi Perusahaan

a. Agar melakukan peningkatan dari segi Citra Merek, Kualitas Produk dan Kualitas Pelayanan, karena ketiga faktor ini secara bersama-sama berpengaruh signifikan terhadap Kepuasan Pelanggan dengan melakukan riset yang mendalam sesuai dengan apa yang diharapkan pelanggan sehingga tercapai Kepuasan Pelanggan yang maksimal.

b. Melakukan riset Kepuasan Pelanggan lebih lanjut karena masih ada faktor-faktor lain yang belum dapat dijelaskan dalam penelitian ini.

2. Bagi Akademisi

a. Bagi pihak lain yang ingin melakukan penelitian sejenis, disarankan untuk meneliti variabel-variabel lain selain Citra Merek, Kualitas Produk dan Kualitas Pelayanan, karena masih ada variabel-variabel lain yang mempengaruhi Kepuasan Pelanggan yang tidak termasuk dalam penelitian ini.

b. Untuk memperkuat hasil penelitian serupa dianjurkan untuk menambah jumlah sampel sehingga hasil penelitian dapat lebih akurat.

\section{DAFTAR PUSTAKA}

Buchari Alma. 2014. Manajemen Pemasaran dan Pemasaran Jasa, Alfabeta, Bandung. Duwi Priyatno. 2015. SPSS 22 Pengolah Data Terpraktis, Andi, Yogyakarta.

Etta Mamang Sangaji \& Sopiah, 2013. Perilaku Konsumen, Pendekatan Praktis, Andi, Yogyakarta.

Fandy Tjiptono. 2014. Pemasaran Jasa, Andi, Yogyakarta.

Fandy Tjiptono. 2015. Strategi Pemasaran, Edisi-4, Andi, Yogyakarta.

Fandy Tjiptono dan Gregorius Chandra. 2012. Pemasaran Strategik, Andi, Yogyakarta.

Freddy Rangkuti. 2009. Riset Pemasaran, PT. Gramedia Pustaka Utama, IKAPI, Jakarta.

Ghozali, Imam. 2013. Aplikasi Analisis Multivariate Dengan Program IBM SPSS 21 Update PLS Regresi, Edisi 7, Badan Penerbit Universitas Diponegoro, Semarang.

Harry. Mobil Murah Ramah Lingkungan,OTOMOTIF, Edisi 50:XXV,21-27 April $2016,04$.

I'anatut Thoifah. 2015. Statistika Pendidikan dan Metode Penelitian Kuantitatif, Madani, Malang.

Keller,Kevin Lane. 2013. Strategic Brand Management Building,Measuring, Managing Brand Equity, Fourth Edition, Pearson,England.

Kotler,Philip dan Kevin Lane Keller.2009. Manajemen Pemasaran,Edisi 12, Jilid 1, Erlangga. Jakarta.

Kotler, Philip dan Kevin Lane Keller.2013. Manajemen Pemasaran, Edisi 13, Jilid 2, Erlangga, Jakarta.

Kotler, Philip and Kevin Lane Keller. 2016.Marketing Management 15e Global Edition. Pearson Education Limited. New Jersey. 
Kotler,Philipand Garry Amstrong. 2014. Principles of Marketing. Fifteenth Edition,Pearson Education Limited, New Jersey.

Muhammad Igor Beladin, Bambang Munas Dwiyanto. 2013. Analisis Pengaruh Kualitas Produk, Kualitas Pelayanan dan Citra Merek Terhadap Kepuasan Konsumen, Journal Of Management, Volume 2, Nomor 2, Universitas Diponegoro, Semarang.

Mario Christo Pesoth. 2015. Pengaruh Kualitas Produk, Packaging,dan Brand Image Terhadap Kepuasan Pelanggan Pada Perusahaan Rokok Dunhill di Kota Malang, Jurnal EMBA, Vol.3 No.3 Sept.2015, Hal. 1101-1112. Universitas Sam Ratulangi Manado.

Muhammad Rizan, Fajar Andika. 2011. Pengaruh Kualitas Produk dan Kualitas Pelayanan Terhadap Kepuasan Pelanggan (Survei Pelanggan Suzuki Dealer Fatmawati Jakarta Selatan), Jurnal Riset Manajemen Sains Indonesia (JRMSI), Vol. 2. No. 1. Universitas Negeri Jakarta.

Nurul Qomariah. 2012. Pengaruh Kualitas Layanan dan Citra Institusi Terhadap Kepuasan dan Loyalitas Pelanggan (Studi Pada Universitas Muhammadiyah di Jawa Timur). Jurnal Aplikasi Manajemen, Volume 10,No. 1, Universitas Muhammadiyah Jember.

Sofjan Assauri. 2014. Manajemen Pemasaran, PT Raja Grafindo Persada, Jakarta.

Sugiyono.2013. Metode Penelitian Kuantitatif, Kualitatif, dan Kombinasi (Mixed Methods), Alfabeta, Bandung.

Supranto, J. 2011. Pengukuran Tingkat Kepuasan Pelanggan, Rineka Cipta, Jakarta.

Sudaryono. 2014. Perilaku Konsumen, Lentera Ilmu Cendekia, Jakarta.

Tim Dosen Pengantar Statistik. 2012. Pendidikan Pengantar Statistik,Universitas Satya Negara Indonesia, Jakarta.

Uma Sekaran.2015. Research Methods For Business, Salemba, Jakarta. 